\title{
Correction to: Strength of correlation between wildlife collision data and hunting bags varies among ungulate species and with management scale
}

\author{
Wiebke Neumann $^{1}$ (D) . Fredrik Widemo ${ }^{1}$ - Navinder J. Singh ${ }^{1} \cdot$ Andreas Seiler $^{2}$ • Joris P. G. M. Cromsigt ${ }^{1,3}$ \\ Published online: 22 October 2020 \\ (C) Springer-Verlag GmbH Germany, part of Springer Nature 2020
}

\section{Correction to: European Journal of Wildlife Research} https://doi.org/10.1007/s10344-020-01421-x

For the first author, the given and family name are mixed up. The correct name is Neumann (Family name), Wiebke (Given name).

The original article has been corrected.

Publisher's note Springer Nature remains neutral with regard to jurisdictional claims in published maps and institutional affiliations.

The online version of the original article can be found at https://oi.org/ 10.1007/s10344-020-01421-x

\section{Wiebke Neumann}

wiebke.neumann@slu.se

1 Department of Wildlife, Fish, and Environmental Studies, Swedish University of Agricultural Sciences, SE-90183 Umeå, Sweden

2 Department of Ecology; Grimsö Wildlife Research Station, Swedish University of Agricultural Sciences, SE-73091 Riddarhyttan, Sweden

3 Centre for African Conservation Ecology, Department of Zoology, Nelson Mandela Metropolitan University, Port Elizabeth, South Africa 